\title{
KERAGAMAN SPESIES DAN PERSEBARAN FAUNA ANURA DI CAGAR ALAM DAN TAMAN WISATA ALAM TELAGA WARNA
}

\author{
Wawan Setiawan ${ }^{1}$, Wahyu Prihatini ${ }^{*}$, Sri Wiedarti $^{1}$ \\ ${ }^{1}$ Program Studi Biologi FMIPA Universitas Pakuan, Bogor \\ *e-mail: wahyu.prihatini@ unpak.ac.id
}

diterima: 12 Agustus 2019; direvisi:19 September 2019; disetujui: 28 September 2019

\begin{abstract}
ABSTRAK
Anura mencakup katak dan kodok, berperan penting sebagai bioindikator kualitas ekosistem, serta pengendalian populasi serangga di alam. Anura sangat peka terhadap perubahan di lingkungan, sejak stadium telurnya. Gangguan terhadap di habitat alaminya, dapat mengancam kelangsungan hidup Anura. Penelitian ini dilakukan di dalam kawasan Cagar Alam dan Taman Wisata Alam Telaga Warna. Pengamatan menggunakan metode Visual Encounter Survey (VES). Analisis yang dilakukan meliputi penghitungan indeks keragaman spesies ShannonWienner, frekuensi pertemuan spesies, dan kepadatan spesies. Hasil penelitian diperoleh 11 spesies Anura dari 5 famili, yaitu Megophryidae, Microhylidae, Ranidae, Dicroglossidae, dan Rhacoporidae. Tingkat keragaman spesies Anura di lokasi penelitian tergolong sedang $\left(\mathrm{H}^{\prime}=\right.$ 0,152). Kepadatan berkisar antara 0,07-0,24 ekor $/ \mathrm{m}^{2}$, dan kepadatan tertinggi ditunjukkan oleh Rhacophorus margaritifer. Frekuensi pertemuan di lokasi sampling berkisar 0,01-3,6\%, dengan frekuensi tertinggi adalah Rana chalconota. Secara umum kualitas ekosistem Telaga Warna cukup baik, terutama di area Rawa Gayung.
\end{abstract}

\section{Kata Kunci: Anura, Keragaman fauna, Bioindikator, kawasan CATWA Telaga Warna \\ DIVERSITY OF SPECIES AND THE DISTRIBUTION OF FAUNA ANURA IN NATURE RESERVE AND NATURAL PARK OF ALAM TELAGA WARNA}

\begin{abstract}
Anura includes frogs and frogs, playing an important role as ecosystem quality bioindicators, as well as insect population control. Anura is very sensitive to changes in the environment, since its egg stadium. Disruption to its natural habitat, can threaten Anura's survival. This research is done in the Nature reserve area and Telaga Warna Natural Nature Park. Observations using the Visual Encounter Survey (VES) method. Analyses conducted include the calculation of the species diversity index of Shannon-Wienner, the frequency of species meetings, and the density of species. The results of the research gained 11 species of Anura from 5 families, namely Megophryidae, Microhylidae, Ranidae, Dicroglossidae, and Rhacoporidae. The level of diversity of Anura species in the research site is moderate $\left(\mathrm{H}^{\prime}=0.152\right)$. Density ranged from 0.07 to 0.24 tails $/ \mathrm{m} 2$, and the highest density is demonstrated by the Rhacophorus margaritifer. The frequency of meetings at a sampling location ranges from 0.01 to $3.6 \%$, with the highest frequency being Rana chalconota. Generally, the quality of the ecosystem of Telaga Warna is good, especially in the area of Gayung Swamp
\end{abstract}

Keywords: Anura, diversity of fauna, bioindicator, CATWA area of Telaga Warna 


\section{PENDAHULUAN}

Hewan katak dan kodok yang termasuk dalam ordo Anura kelas Amfibia, sangat peka terhadap perubahan kualitas lingkungan, misalnya pencemaran air, hilangnya habitat, maupun perubahan iklim. Apabila di suatu wilayah tidak ditemukan katak atau kodok, hal ini mengindikasikan kualitas lingkungan di wilayah tersebut sangat buruk (Iskandar \& Mumpuni, 2004 dalam IUCN, 2007).

Katak dan kodok berperan penting sebagai bioindikator kualitas lingkungan, dan pengendalian populasi serangga di alam. Katak dan kodok juga memberikan manfaat bagi manusia, antara lain sebagai sumber protein hewani berupa daging paha katak beku, yang menjadi komoditi ekspor penting (Sparling, et.al., 2000).

Katak dan kodok sangat peka terhadap perubahan lingkungan, bahkan sejak stadium telurnya. Kerusakan hutan, pencemaran sungai, maupun konversi lahan, menjadi penyebab berkurang, atau bahkan hilangnya habitat alami katak dan kodok (Kusrini, 2009). Di wilayah Jawa Barat diketahui terdapat 28 spesies Anura dari 6 famili: Bufonidae, Dicroglossidae, Microhylidae, Megophyridae, Ranidae, dan Rhacophoridae (Kusrini, 2013).

Cagar Alam dan Taman Wisata Alam (CATWA) Telaga Warna merupakan kawasan konservasi yang berpotensi untuk dikembangkan sebagai kawasan ekowisata. Peraturan Pemerintah No. 28 Tahun 2011 menyatakan fungsi utama Taman Wisata Alam adalah sebagai lokasi pariwisata, dan rekreasi alam, namun di sisi lain kegiatan tersebut dikhawatirkan dapat menurunkan kualitas lingkungan CATWA Telaga Warna sebagai kawasan konservasi.

Berdasarkan uraian tersebut, perlu dilakukan inventarisasi keragaman spesies dan persebaran satwa Anura di CATWA Telaga Warna, yang dapat menjadi indikator kualitas lingkungan kawasan ini. Penelitian ini bertujuan untuk mengidentifikasi keragaman spesies, dan persebaran satwa Anura di kawasan CATWA Telaga Warna, sebagai alah satu cara pemantauan kualitas lingkungan di kawasan tersebut.

\section{BAHAN DAN METODE Bahan}

Penelitian berlokasi di Cagar Alam dan Taman Wisata Alam Telaga Warna, Bogor, Jawa Barat. Bahan-bahan yang digunakan dalam penelitian, yaitu sampel katak dan kodok dari lokasi penelitian. Peralatan yang digunakan: sweeping net, jangka sorong, penggaris, senter, sarung tangan, termometer, hygrometer, DO meter, $\mathrm{pH}$ meter, buku panduan identifikasi Anura, dan kamera.

\section{Metode}

Penelitian dilakukan menggunakan metode Visual Encounter Survey (VES), dan mengamati obyek penelitian dalam suatu periode waktu. Waktu disini dimaknai sebagai jumlah jam pencarian per orang pada suatu lokasi pengamatan, sehingga menjadi data yang terukur, dan bisa diperbandingkan (Kusrini, 2009).

Pengambilan data primer dilakukan dengan tahap-tahap sebagai berikut:

a. survey pendahuluan untuk menetapkan lokasi pengamatan;

b. pembuatan tiga plot di setiap lokasi pengamatan, masing-masing berukuran $10 \times 10 \mathrm{~m}^{2}$.

c. pengumpulan sampel di setiap plot dilakukan pada pukul 18.00-23.00 WIB.

d. pengumpulan data fisika-kimia lingkungan di setiap plot pengamatan.

e. identifikasi spesies yang ditemukan, menggunakan buku "Panduan Bergambar Identifikasi Amfibi Jawa Barat" (Kusrini, 2013).

\section{Analisis Data}

a. Indeks Keragaman Spesies

Analisis keragaman spesies Anura di lokasi penelitian berdasarkan indeks Shannon-Wienner (Brower \& Zar, 1997), dengan rumus: 
$\mathrm{H}^{\prime}=-\left\{\sum(\mathrm{ni} / \mathrm{n}) \ln (\mathrm{ni} / \mathrm{n})\right\}$

dengan :

H' = indeks Shannon-Wienner

$\mathrm{n}_{\mathrm{i}}=$ jumlah spesies (i)

$\mathrm{N}=$ total jumlah individu

b. Frekuensi spesies

Analisis frekuensi perjumpaan spesies Anura di lokasi pengamatan (Brower \& Zar, 1997), dengan rumus:

Frekuensi spesies $=$ jumlah plot ditemukannya spesies i, dibagi jumlah total plot pengamatan, dikalikan $100 \%$.

c. Kepadatan
Kepadatan suatu spesies (K) dihitung dengan rumus (Brower \& Zar, 1997):

$\mathrm{K}_{\text {spesies }}=$ Jumlah individu spesies A pada suatu plot Luas plot pengamatan $\left(\mathrm{m}^{2}\right)$

d. Analisis persebaran, dan waktu perjumpaan setiap spesies Anura yang dijumpai di lokasi pengamatan.

e. Parameter fisika-kimia lingkungan yang diukur, meliputi suhu, $\mathrm{pH}$, kelembaban udara, serta dan DO.

\section{HASIL DAN PEMBAHASAN}

Hasil penelitian mendapati 11 spesies Anura dari 5 famili, yaitu Megophryidae, Microhylidae, Ranidae, Dicroglossidae, dan Rhacoporidae dapat dilihat pada Tabel 1.

Tabel 1. Ragam spesies dan jumlah Anura di lokasi pengamatan

\begin{tabular}{|c|c|c|c|c|c|c|}
\hline \multirow{2}{*}{ No } & \multirow{2}{*}{ Famili } & \multirow{2}{*}{ Spesies } & \multicolumn{3}{|c|}{ Lokasi (ekor) } & \multirow{2}{*}{ Jumlah (ekor) } \\
\hline & & & $\mathrm{A}$ & $\mathrm{B}$ & $\mathrm{C}$ & \\
\hline \multirow{3}{*}{1} & \multirow{3}{*}{ Dicroglossidae } & Fejervarya limnocharis & - & 1 & - & 1 \\
\hline & & Limnonectes kuhlii & - & 1 & 7 & 8 \\
\hline & & Limnonectes microdiscus & - & - & 2 & 2 \\
\hline \multirow{2}{*}{2} & \multirow{2}{*}{ Microhylidae } & Microhyla achatina & 2 & - & - & 2 \\
\hline & & Microhyla phalmipes & 1 & - & - & 1 \\
\hline 3 & Megophryidae & Megophrys montana & - & 1 & - & 1 \\
\hline 4 & Ranidae & Rana chalconota & 11 & 8 & 2 & 21 \\
\hline \multirow{5}{*}{5} & \multirow{4}{*}{ Rhacophoridae } & Nyctixalus margaritifer & - & 1 & - & 1 \\
\hline & & Philautus auriafasciatus & - & 4 & - & 4 \\
\hline & & Rhacophorus margaritifer & - & 24 & 1 & 25 \\
\hline & & Rhacophorus reinwardtii & - & 3 & - & 3 \\
\hline & & Jumlah & 14 & 43 & 12 & 69 \\
\hline
\end{tabular}

Keterangan: $\mathrm{A}=$ Danau Telaga Warna; $\mathrm{B}=$ Rawa Gayung; $\mathrm{C}=$ Curug Nonggeng

Tampak pada Tabel 1 bahwa lokasi yang memiliki jumlah spesies Anura tertinggi adalah Rawa Gayung (8 spesies), diikuti oleh Curug Nonggeng (4 spesies), dan terendah yaitu area Danau Telaga Warna (3 spesies). Jumlah spesies Anura di Curug Nonggeng tidak terlalu berbeda dengan temuan Octaviani (2010) yang menjumpai tiga spesies.

Rawa Gayung merupakan kawasan inti CATWA Telaga Warna yang memiliki beragam spesies tumbuhan, dan sungai berarus lambat, berbeda dengan area sekeliling Danau Telaga Warna, ataupun area Curug Nonggeng. Jumlah spesies Anura di area Rawa Gayung yang lebih tinggi dibandingkan dua lokasi lainnya, sangat mungkin disebabkan area ini merupakan perbatasan hutan primer dengan perkebunan. Beberapa spesies Anura diketahui menyukai kawasan hutan yang tak terganggu manusia, dan tersedia berbagai spesies pakannya, seperti semut, kumbang kecil, larva serangga, dan hewan-hewan kecil lain yang melimpah (Kusrini, 2013).

Spesies Rhacophorus margaritifer (katak pohon Jawa) adalah spesies yang paling banyak ditemukan, di area Rawa Gayung khususnya mereka banyak dijumpai di sepanjang alur rawa. Katak ini diketahui tersebar di hutan primer pada ketinggian di atas 250-1500 m dpl (Kusrini, 2013). Di Kawasan CATWA Telaga Warna katak ini sering ditemukan bertengger pada cabang 
batang semak, ranting pohon dan dedaunan lebar, pada tutupan tajuk yang relatif tertutup di tepi sungai, atau selokan, serta sumber air lainnya.

Persebaran $R$. margaritifer terbatas di Pulau Jawa, antara lain di Kawasan Taman Nasional G. Gede Pangrango, G. Malabar (daerah Bogor), Lawang, dan Gua Ngerong (Jawa Timur). Status konservasi spesies ini adalah least concern (LC) atau beresiko rendah, dan populasinya diketahui cenderung stabil (IUCN, 2015).

Spesies terbanyak kedua yang ditemukan di area Rawa Gayung, adalah Rana chalconota (kongkang kolam). Satwa ini menyukai lingkungan hutan primer maupun sekunder, dan banyak ditemukan di sepanjang aliran sungai (IUCN, 2004). Spesies ini tersebar mulai dari Thailand, Pulau Nicobar, Semenanjung Malaysia, Sumatra, Kalimantan, Jawa, Bali dan Sulawesi (Kusrini, 2013). Status konservasi spesies ini yaitu Least concern (LC) atau beresiko rendah, dan populasinya di alam diperkirakan stabil (IUCN, 2015).

Spesies lain yang dijumpai di dalam hutan Rawa Gayung adalah Nyctixalus margaritifer (katak pohon mutiara) yang berstatus rentan (vulnerable). Spesies ini diketahui hanya hidup di dalam hutan-hutan yang tidak terganggu, dan populasinya di alam diperkirakan terus menurun (IUCN, 2015).

Katak endemik P. Jawa ini sering bersembunyi di lubang-lubang kayu, sehingga sukar ditemukan. $N$. margaritifer dijumpai mulai dari hutan dataran rendah hingga ketinggian $1.200 \mathrm{~m} \mathrm{dpl} \mathrm{(Kusrini,}$ 2013). Di lokasi pengamatan, katak ini ditemukan di atas daun talas dekat pepohonan. Pernah pula dilaporkan katak ini ditemukan di Cilember, dan TWA Situ Gunung (Kusrini, 2013). Berdasarkan hasil temuan spesies-spesies Anura di area Rawa Gayung dalam penelitian ini, dapat dikatakan bahwa lokasi tersebut sangat ideal sebagai habitat Anura.

Hasil analisis indeks keragaman spesies Shannon-Wienner mendapati nilai indeks keragaman $\mathrm{H}^{\prime}=0,152$; yang berarti tingkat keragaman spesies Anura pada tiga lokasi pengamatan tergolong sedang (Iskandar, 1998). Tingkat keragaman spesies ini diduga tidak lepas dari pengaruh kehadiran pengunjung ekowisata CATWA Telaga Warna (Tabel 2), dan aktivitas pembangunan di sekitar Kawasan ini.

Tabel 2. Jumlah pengunjung CATWA Telaga Warna

\begin{tabular}{ccc}
\hline No & Bulan & Pengunjung (orang) \\
\hline 1 & November 2016 & 1.726 \\
\hline 2 & Desember 2016 & 2.007 \\
\hline 3 & Januari 2017 & 3.889 \\
\hline
\end{tabular}

Jumlah pengunjung CATWA Telaga Warna khususnya di sekitar danau Telaga Warna, periode November 2016 sampai Januari 2017 menunjukkan peningkatan. Meningkatnya jumlah, dan aktivitas pengunjung tentu berdampak terhadap kualitas mikrohabitat satwa, termasuk habitat Anura. Kondisi ini diduga yang menjadi penyebab utama penurunan keragaman spesies Anura di CATWA Telaga Warna. Keragaman spesies Anura pada penelitian ini lebih rendah dibandingkan temuan Octaviani (2010) di kawasan yang sama, yang mendapati 22 spesies dari enam famili, yaitu Ranidae, Dicroglossidae, Megophryidae, Bufonidae, Microhylidae, dan Rhacoporidae.

\section{Posisi Horisontal dan Vertikal Anura}

Perjumpaan dengan Anura di lokasi pengamatan terlihat pada posisi horizontal, maupun vertikal (Tabel 3). Pada hewan Anura, posisi horizontal adalah posisi hewan terhadap badan perairan, yang dipengaruhi oleh naungan, dan tipe tepian. Adapun posisi vertikal adalah posisinya pada sub permukaan tanah terbuka, pada tanah di bawah naungan, di bawah tanah, ataupun air (Kusrini, 2009)

Umumnya spesies Anura yang dijumpai dalam penelitian ini adalah spesies-spesies yang membutuhkan air. Sebagai contoh, Limnonectes kuhlii (bangkong tuli) sering dijumpai di bebatuan pada aliran air, dan Limnonectes microdiscus (bangkong kerdil) 
dijumpai di tanah, atau bebatuan di tepi sungai yang tergenang air. Kedua spesies katak akuatik ini sangat membutuhkan perairan untuk melarikan diri jika terganggu. Adapun Rana chalcone jika menjumpai gangguanota sering terlihat menggunakan semak-semak di tepi perairan untuk bersembunyi (Nasir dkk., 2003).

Aktivitas Anura yang teramati pada penelitian ini dapat dikelompokkan dalam beberapa aktivitas, yaitu duduk diam atau istirahat, memanggil (calling), berenang, dan bergerak. Aktivitas yang paling sering teramati adalah duduk diam atau istirahat. Beberapa spesies Anura sangat peka terhadap gangguan di sekitarnya, contohnya Microhyla achatina (percil Jawa), Microhyla phalmipes (percil berselaput), dan Limnonecte kuhlii (bangkong tuli). Ketiga spesies tersebut biasanya segera melompat, atau menyelam ke dalam air, jika ada manusia mendekati lokasi mereka (Nasir dkk., 2003).

Tabel 3. Posisi horizontal dan vertikal spesies Anura di lokasi pengamatan

\begin{tabular}{llll}
\hline No & \multicolumn{1}{c}{ Spesies } & \multicolumn{1}{c}{ Posisi horizontal } & \multicolumn{1}{c}{ Posisi vertikal } \\
\hline 1 & Fejerivarya limnocharis & di tengah air (rawa) & di rumput \\
\hline 2 & Limnonectes kuhlii & di tengah sungai & $\begin{array}{l}\text { di batu, celah batu, permukaan } \\
\text { tanah basah }\end{array}$ \\
\hline 3 & Limnonectes microdiscus & di tengah sungai & di atas batu dan rumput \\
\hline 4 & Microhyla achatina & di tepi dan sekitar badan air & di rumput dan tanah terbuka \\
\hline 5 & Microhyla phalmipes & di tepi dan sekitar badan air & di rumput \\
\hline 6 & Leptobrachium montana & di tepi air & di bebatuan, diserasah \\
\hline 7 & Rana chalconota & di tepi air & di rumput, kadang di batu \\
\hline 8 & Nyctixalus margaritifer & di tepi air & di atas pohon \\
\hline 9 & Philautus auriafasciatus & di tepi air & di daun \\
\hline 10 & Rhacophorus margaritifer & di tepi sungai & di daun \\
\hline 11 & Rhacophorus reinwardtii & di tepi sungai & di daun \\
\hline
\end{tabular}

Spesies Anura lain yang ditemukan juga cepat melompat ke air jika terganggu, adalah Rhacophorus margaritifer, Fejervarya limnoholi (katak tegalan), Rana chalconota, dan Limnonectes microdiscus. Katak $R$. chalconota jantan saat dijumpai pengamat, sedang melakukan aktivitas memanggil (calling), namun langsung diam ketika pengamat mendekat. Perilaku menghindar yang serupa juga dijumpai pada L. kuhlii yang mudah dikenali suaranya. Jika tertangkap, mereka langsung bereaksi mengeluarkan cairan pada seluruh kulitnya (Nasir dkk., 2003).

\section{Kepadatan dan Frekuensi Perjumpaan}

Kepadatan spesies Anura di lokasi pengamatan berkisar $0,07-0,24 \mathrm{ekor} / \mathrm{m}^{2}$, dan kepadatan tertinggi ditunjukkan oleh Rhacophorus margaritifer $\left(0,24\right.$ ekor $\left./ \mathrm{m}^{2}\right)$ yang dijumpai di seluruh area, terutama sepanjang alur rawa. Hal ini diduga terkait dengan banyaknya rerumputan, dan pepohonan yang rapat.

Frekuensi perjumpaan R.margaritifer juga tertinggi $(0,08 \%)$ dari seluruh spesies yang dijumpai dalam penelitian ini. Spesies ini juga sering ditemukan di sekitar kolam buatan berarus lambat. Spesies lain yang juga sering dijumpai di semua lokasi pengamatan dengan frekuensi tertinggi ke dua $(0,02 \%)$, adalah Rana chalconota. Spesies ini sering terlihat di sepanjang alur rawa. atau tepi selokan yang berarus lambat. $R$. chalconota diketahui menyukai lingkungan hutan, primer maupun sekunder, dan biasa ditemukan dalam jumlah banyak pada vegetasi, dan bebatuan di sepanjang aliran sungai (IUCN, 2007). 
Beberapa spesies Anura lainnya yang tidak sering dijumpai, dan kepadatannya relatif rendah, adalah Microhyla phalmipes, Megophrys montana, Nyctixalus margaritifer dan Fejervarya limnocharis. Berdasarkan karakteristik biologi dan status konservasi spesies Anura yang ditemukan di area Rawa Gayung, dapat dikatakan bahwa lokasi ini sangat sesuai sebagai habitat Anura. Dapat dikatakan bahwa area Rawa Gayung memiliki keragaman spesies Anura paling tinggi, dan merupakan habitat yang sangat cocok bagi kehidupan Anura.

\section{Kesesuaian Habitat Anura}

Peubah kimia fisika pada tiga lokasi pengamatan di dalam Kawasan CATWA Telaga Warna secara umum sesuai untuk kehidupan, dan persebaran Anura (Tabel 4). Beberapa faktor lingkungan yang memengaruhi kehidupan dan persebaran Anura, antara lain adalah suhu, $\mathrm{pH}$ perairan, kelembaban, dan struktur hutan. Anura tidak tahan terhadap sinar matahari langsung, sehingga kerapatan vegetasi di lingkungannya memengaruhi kondisi fisik dan biologi Anura (Wong, 2003 dalam Pujaningsih, 2007).

Suhu di lokasi pengamatan secara umum sesuai untuk kehidupan Anura. Pujaningsih (2007) menyebutkan bahwa untuk pertumbuhan yang optimal, Anura menyukai kisaran suhu $19-31^{\circ} \mathrm{C}$. Anura mutlak memerlukan air untuk bertelur, dan berkembangnya larva (berudu). Suhu lingkungan berpengaruh terhadap laju metabolisme, pertumbuhan, perilaku, kerentanan terhadap penyakit, dan mortalitas suatu organisme. Secara fisika, suhu lingkungan menentukan konsentrasi gas terlarut dalam perairan (Ardiansyah dkk., 2014), dan hal tersebut sangat berpengaruh terhadap biota akuatik.

Kondisi pH air dan tanah di lokasi pengamatan juga sesuai untuk kehidupan Anura (Pujaningsih, 2007). Kondisi pH perairan sangat menentukan keberhasilan dan pertumbuhan telur, serta berudu Anura. Kondisi $\mathrm{pH}$ tanah berpengaruh terhadap vegetasi, yang mendukung kelangsungan hidup Anura, karena berfungsi sebagai tempat berlindung, dan mendapatkan pakan.

Tabel 4. Peubah kimia fisika lingkungan di lokasi pengamatan

\begin{tabular}{clccc}
\hline No & \multicolumn{1}{c}{ Peubah } & DanauTelaga Warna & Rawa Gayung & Curug Nonggeng \\
\hline 1 & Kelembaban $(\%)$ & 70 & 72 & 72 \\
\hline 2 & pH air & 5 & 5 & 5 \\
\hline 3 & pH tanah & 5 & 5 & 6 \\
\hline 4 & Suhu air $\left({ }^{0} \mathrm{C}\right)$ & 21 & 21 & 19 \\
\hline 5 & Suhu udara $\left({ }^{\circ} \mathrm{C}\right)$ & 21 & 20 & 20 \\
\hline 6 & DO $(\mathrm{mg} / \mathrm{L})$ & 20,3 & 24,5 & 26,1 \\
\hline
\end{tabular}

Rataan kandungan DO perairan di area Curug Nonggeng tercatat 26,1 $\mathrm{mg} / \mathrm{L}$, di Rawa Gayung 24,5 mg/L, dan di area Danau Telaga Warna $20,3 \mathrm{mg} / \mathrm{L}$. Nilai DO yang lebih tinggi pada bagian hulu sungai (area Curug Nonggeng) dipengaruhi oleh suhu air yang lebih rendah. Semakin rendah suhu air semakin tinggi kandungan DO. Nilai DO di semua lokasi pengamatan secara umum sesuai untuk kehidupan Anura. Barus (2004) menyatakan bahwa kehidupan biota akuatik dapat bertahan pada kandungan DO minimum $5 \mathrm{mg} / \mathrm{L}$.
Area Rawa Gayung yang merupakan kawasan inti CATWA Telaga Warna memiliki beragam jenis tumbuhan, serta sungai berarus lambat. Serasah, lumut, dan pepohonan di area ini sangat rapat, terlebih dengan adanya hutan primer yang menjadikan area Rawa Gayung sangat ideal sebagai habitat alami Anura. Tidak mengheranjkan jika area ini memiliki keragaman spesies Anura yang paling tinggi dibandingkan dua lokasi lainnya.

Area sekeliling Danau Telaga Warna memiliki banyak tajuk tertutup, dan semaksemak rapat. Terdapat pula beberapa area 
terbuka yang ditumbuhi rerumputan, dan pepohonan dengan kerapatan jarang, serta tumbuhan talas yang mengelompok di sekitar danau. Kondisi lingkungan yang agak terbuka, dan cukup banyak didatangi pengunjung kurang disukai oleh beberapa spesies Anura, sehingga perjumpaan Anura di area ini cukup rendah.

Lokasi pengamatan Curug Nonggeng memiliki vegetasi dengan tajuk relatif terbuka, dan rumput yang jarang-jarang di sepanjang alur curug, serta sungai berarus deras. Terdapat banyak celah batuan di sepanjang, dan tepi aliran curug, serta lubang-lubang yang dihuni beberapa spesies Anura. Pada siang hari tidak banyak aktivitas masyarakat di wilayah ini.

Kondisi lingkungan Curug Nonggeng cocok untuk beberapa spesies Anura tertentu yang menyukai perairan berarus deras, dan banyak bebatuan. Katak-katak muda umumnya dapat ditemukan di antara bebatuan, atau di atas lumpur di tepi selokan, dan sungai. Katak dewasa biasa ditemukan pada lubang-lubang di antara bebatuan. Secara umum keragaman Anura yang dijumpai di lokasi ini adalah yang paling rendah jumlah spesiesnya dalam peneltian ini

\section{KESIMPULAN}

Penelitian ini mendapatkan 11 spesies Anura di kawasan Cagar Alam dan Taman Wisata Alam Telaga Warna, yaitu Rana chalconota, Limnonectes kuhlii, Fejervarya limnocharis, Philautus auriafasciatus, Limnonectes microdiscus, Rhacophorus margaritifer, Megophrys montana, Microhyla achatina, Microhyla phalmipes, Nyctixalus margaritifer, dan Rhacophorus reinwardtii. Tingkat keragaman spesies Anura tergolong sedang, berdasarkan skala indeks Shannon Wienner.

\section{DAFTAR PUSTAKA}

Ardiansyah, D., A. Karunia, T. Auliandina, D.A. Putri, M.I. Noer. (2014). Kelimpahan Kodok Jam Pasir Leptophryne borbonica di Sepanjang Aliran Sungai Cisuren, Bodogol, Taman
Nasional Gunung Gede Pangrango. Bioma 10(2):2.

Barus, T.A. (2004). Pengantar Limnologi. Studi Tentang Ekosistem Air Daratan. USU Press. Medan. 23

Brower, J.E., J.H. Zar. (1997). Fieled and Laboratory Medhods for General Ecology. Jakarta. 21

IUCN. (2004). The IUCN Red List of Threatened Species. Diakses pada tanggal 21 Juni 2016 pk. 12.05 WIB.

IUCN. (2007). The IUCN Red List of Threatened Species. Diakses pada tanggal 21 Juni 2016 pukul 02.30 WIB.

IUCN. (2015). The IUCN Red List of Threatened Species. Diakses pada tanggal 21 Juni 2016 pukul 02.50 WIB

Iskandar, D. T. (1998). Amfibi Jawa dan Bali. Seri Panduan Lapangan. Puslitbang LIPI. Bogor.1-3.

Kusrini, M. D. (2009). Pedoman Penelitian dan Survei Amfibi di Alam. IPB. Bogor. 19

Kusrini, M. D. (2013). Panduan Bergambar Identifikasi Amfibi Jawa Barat. Fahutan IPB dan Direktorat KKH. Bogor. 30.

Nasir, M.D., A. Priyono, M.D. Kusrini. (2003). Keanekaragaman Amfibi (Ordo Anura) di Sungai Ciapus Leutik, Bogor, Jawa Barat. LIPI. 61.

Octaviani, R. (2010). Keragaman dan Kelimpahan Anura. Skripsi Program Studi Biologi, Fakultas Matematika dan Ilmu Pengetahuan Alam, Universitas Pakuan. 17-19.

Pujaningsih, R.I. (2007). Seri Budidaya Kodok Lembu. Kanisius. Yogyakarta. 26

Sparling, D.W., G. Linder, C.A. Bishop. (2000). Ecotoxicology of Amphibians and Reptiles. SETAC Technical Publications. Colombia. 87. 